Article

\title{
Investigation of Waste Paper Cellulosic Fibers Utilization into Cement Based Building Materials
}

\author{
Viola Hospodarova ${ }^{1, *}$, Nadezda Stevulova ${ }^{1}{ }^{(\mathbb{D}}$, Jaroslav Briancin ${ }^{2}$ and Katarina Kostelanska ${ }^{3}$ \\ 1 Institute of Environmental Engineering, Faculty of Civil Engineering, Technical University of Kosice, \\ 04200 Kosice, Slovakia; nadezda.stevulova@tuke.sk \\ 2 Institute of Geotechnics, Slovak Academy of Science, 04001 Kosice, Slovakia; briancin@saske.sk \\ 3 Greencel Ltd., 09302 Hencovce, Slovakia; katarina.kostelanska@bukoza.sk \\ * Correspondence: viola.hospodarova@tuke.sk; Tel.: +421-55-602-4278
}

Received: 25 November 2017; Accepted: 12 March 2018; Published: 14 March 2018

\begin{abstract}
Recently, the utilization of renewable natural cellulosic materials, such as wood, plants, and waste paper in the preparation of building materials has attracted significant interest. This is due to their advantageous properties, low environmental impact and low cost. The objective of this paper is to investigate the influence of recycled cellulosic fibers (in the amount $0.5 \mathrm{wt} \%$ of the filler and binder weight) and superplasticizer (in the amount $0.5 \mathrm{wt} \%$ of the cement weight) on the resulting properties of cement composites (consistency of fresh mixture, density, thermal conductivity, and compressive and flexural strength) for hardening times of 1, 3, 7, 28, and 90 days. Plasticizer use improved the workability of fresh cement mixture. In comparison to the reference sample, the results revealed a decrease in density of $6.8 \%$ and in the thermal conductivity of composites with cellulosic fibers of $34 \%$. The highest values of compressive ( $48.4 \mathrm{MPa}$ ) and flexural (up to $7 \mathrm{MPa}$ ) strength were achieved for hardened fiber cement specimens with plasticizer due to their significantly better dispersion of cement particles and improved bond strength between fibers and matrix.
\end{abstract}

Keywords: waste paper fibers; cement composites; building materials; renewable material

\section{Introduction}

A key issue in building construction is the development of innovative construction materials, because this sector is one of the most energy- and resource-consuming sectors and is responsible for considerable carbon dioxide emissions. Nowadays, due to the rise of environmental consciousness and awareness of industrial pollution, industries such as building, construction and manufacturing must necessarily ensure production of reliable and environmentally friendly materials. One of the ways of doing so is the reuse of industrial by-products or waste [1-4], as well as the use of natural renewable sources, which are generally considered necessary choices in construction. The replacement of conventional synthetic fibers by natural cellulosic fibers has occupied the attention of researchers, as well $[5,6]$. Due to their physical, chemical, and mechanical properties, cellulosic fibers have the potential to be used in the building industry [7,8], for reinforcing plasters [9].

Natural ligno/cellulosic fibers are widely available and are produced in large quantities and various morphologies (in the form of pulp or short filament fibers), aspect ratios, and sizes across the world. They are derived from renewable sources, such as wood, annual plants, agro-industrial and waste material. They provide significant improvement over the characteristics of cement-based materials or materials based on organic matrices, given their low density, their bio-renewable character, and their availability throughout the world. They are low-cost in comparison to synthetic fibers, have no known health hazards, have adequate stiffness and strength, are easy to process and recycle, and are eco-friendly $[7,10-12]$. The physico-mechanical properties of fiber-cement-based composites 
depend on the fiber-matrix interactions. The interface controls the strength of composite materials, because stress is transferred from fiber to fiber through the matrix [13].

There is a growing trend to incorporate considerable portions of natural, waste, or recycled cellulosic materials in the development of new building materials. Progress in the production of lasting cement mortar composites reinforced with fibers and especially natural fibers or waste fibers is an interesting alternative available for the building sector in the fields of thin walls/thin-sheet partitions, building envelope/ceilings flat sheets, roofing tiles and pre-manufactured components [12]. Many studies have described the behavior of cement composites with agricultural by-products or waste based on ligno/cellulosic nature fibers/aggregates from bamboo [14], hemp hurds [15-17], and coconut [18]. A review of the research results obtained in the last few years in the field of cement-based composites/mortars reinforced with cellulosic fibers focusing on their composition, preparation methods, mechanical properties, and strategies for improving fiber-matrix bonding and composite durability is given in [19].

Cellulosic fibers contribute to the development of high-quality, environmentally friendly building materials. Building materials reinforced with fibers are used in a wide range of applications, from building, plastering and mortaring systems to non-load-bearing composites and decorative applications $[20,21]$. While the properties of cement-based building materials reinforced with the natural cellulosic fibers from plants and agricultural crops are abundantly described in the literature sources, the implementation of cellulosic fibers coming from waste paper in cement mortars/composites has still not been sufficiently investigated, even if waste paper is an important source of cellulosic fibers. There are just a few of examples of a successful recycled cellulosic fiber application in cement-based composites. Cellulosic fibers obtained from waste paper packaging [10], waste packaging boxes, and papers $[6,15,22]$ were used in cement composites. As shown in paper [23], these cement-based composite systems present a tension-softening behavior with low tensile ultimate strength, resulting in products that are more suitable for non-structural applications. The known products manufactured with recycled cellulosic fibers are plasterboard, insulation materials for the thermal insulation of walls and floors, sound insulation of ceilings and roofs, as well as bricks made of waste paper fibers agglomerated with cement [24]. In the field of cement-based plaster mortars based on the recycled cellulosic fibers the low number of literature sources is recorded. As shown in [25], the addition of waste fibers resulted in improved mechanical properties of mortars hardened for 28 days, compared to the control mortar. An increase of $4 \%$ was observed in tensile resistance on flexural stress, and of $7 \%$ in compression strength for the mortar prepared with $1.5 \%$ cellulose pulp. The properties of density, adhesion to the support layer, bending and compressive strength, capillary absorption, and fire behavior of cement mortar reinforced by recycled cellulosic fibers were studied in [24]. A technology was developed with minimal embodied energy ensuring lightweight plastering mortars with very good thermal insulation characteristics, compressive strength assigned to class CS I or CS II and water absorption by capillarity classified as W0 or W1. New ecological plastering mortars based on waste cellulosic fibers (newsprint or copy paper) were produced, and their properties were investigated [24]. As given in this paper, the study oriented towards the use of recycled fibers in cement mortars opens the way to new recipes for the manufacture of environmentally friendly plastering mortars and other building materials with improved technically important characteristics. At the same time, this pathway will contribute to reducing the quantities of waste paper, as well.

On the other hand, the main drawback associated with cellulosic fibers in the application of cement composites is their durability in cementitious matrix. Recently, the problem of their durability was analyzed in detail in [26]. The cell structure of cellulosic fibers has good mechanical properties with low density; this is also the reason for natural fibers' poor durability in alkaline environments (cement matrix) as a result of the formation of porous networks in cement during the hardening of cement paste. Natural cellulosic fibers exposed to alkaline and the mineral-rich environment of the cement matrix results in degradation and brittleness due to two aging mechanisms: alkaline hydrolysis and cell wall mineralization. This significantly affects the reinforcing role of cellulosic fibers 
in cement composites [26]. Their durability is further affected by strength, but this is not the only factor. The strength of the composites is influenced by several factors, including the strength of the matrix, the matrix/fiber interfacial bond, and fiber strength [27]. According to [28], durability of concrete was also dependent on the type of cement. Concrete is specified there in terms of both strength and durability. However, [29] describes the durability improvement of ordinary cement-based composites incorporating sisal fibers by partially replacing Portland cement by metakaolin and crushed waste calcined clay bricks. The durability of the sisal, fiber-cement mortar laminates was determined using wetting and drying cycles in a forced air flow chamber. The composites' durability was evaluated by testing the flexural toughness and the post-cracking flexural strength. The behavior of sisal fibers in pure and metakaolin modified cement matrices was tested in work [26]. The degradation degree of sisal fibers was determined by analyzing surface morphology, crystallinity index, and thermal and uniaxial tensile characteristics of the fibers. Increase in the durability of fibers by reducing alkalinity of the pore solution (metakaolin effectively mitigates the deterioration of natural fibers) was observed.

The use of various types and dimensions of cellulosic fibers into cement composites caused reduction in the matrix brittleness and increase in the durability: this was found to be proportional to the resistance to crack propagation, because the use of natural fibers bridged the matrix and effectively transferred the load [12,30]. Cellulosic fibers are also known to decrease thermal conductivity [6], improve acoustic performance by increasing sound absorption [31], reduce density, and increase the flexural strength [32], control of the initiation, and growth of micro-cracks [30].

The aim of this paper is to investigate the influence of recycled waste paper fibers and plasticizer on workability of fresh mixtures and on final physical, mechanical, and thermal properties of 28-day hardened fiber-cement based composites. Development of compressive strength was observed up to 90 days of hardening time. For comparison, a reference sample containing only cement, sand, and water was prepared. New perspective is provided by this work in accordance with the principles of sustainable construction on the implementation of recycled cellulosic fibers, which are not commonly used in cement plasters (for use in interiors).

\section{Materials and Methods}

\subsection{Materials}

The cellulosic fibers (Figure 1) used in this study come from different sources of recycled waste papers (newspapers, magazines, and cartons). Cellulosic fibers were obtained right after pulping in raw state without further treatment. These unbleached recycled cellulosic fibers (G-3/00T) of grey color with $80 \%$ cellulose content were provided by the Slovak Company Greencel, Ltd. (Hencovce, Slovakia). Their properties are shown in Table 1. Cellulosic fibers were used as a $0.5 \mathrm{wt} \%$ addition with reference to filler and binder weight. Portland cement type CEM I $42.5 \mathrm{~N}$, from Cement Factory Ltd. (Povazska Cementaren Ladce, Slovakia), was used for preparing cement composites. Standard silica sand supplied by the company Filtracni Pisky Ltd. (Chlum, Czech Republic) conforming to the standard [33] was used as filler. Water for the cement mixtures' preparation was used in accordance with the standard [34]. A high efficiency polycarboxylate-based superplasticizer, MasterGlenium Sky 665, was acquired from the BASF-Chemical Company Ltd. (Prague, Czech Republic); this was added to enhance the workability of the fiber-containing mortar and was taken according to the standard [35]. The particular configuration of the Master Glenium SKY 665 molecules allows their delayed adsorption onto the cement particles and disperses them effectively over a long period of time. They leave sufficient area on the surface of the cement particles to allow a rapid hydration reaction, resulting in high early strength development. Additionally, this superplasticizer provides powerful water reducing capacity, high early and final strength with maintained flowability, and improves workability of the fresh mixture. 


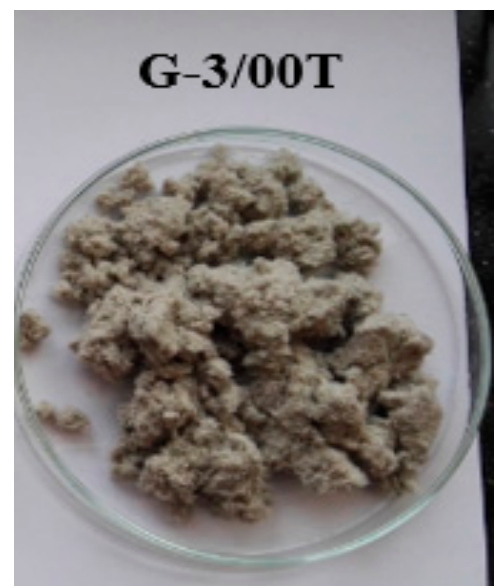

(a)

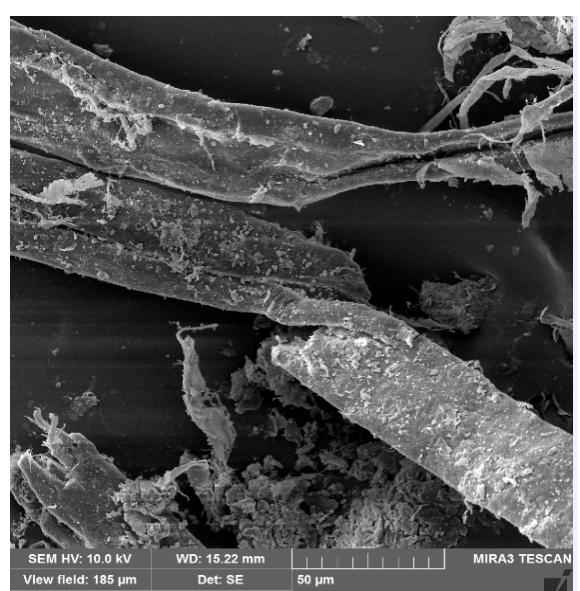

(b)

Figure 1. Recycled waste paper fibers G-3/00T Greencel: (a) macro view; (b) SEM image at 1500 times magnification.

Table 1. Properties of recycled waste paper cellulosic fiber Greencel.

\begin{tabular}{|c|c|c|c|c|c|c|c|}
\hline $\begin{array}{c}\text { Characteristic } \\
\text { of Cellulosic } \\
\text { Fiber }\end{array}$ & $\begin{array}{l}\text { Max. } \\
\text { Length } \\
(\mu \mathrm{m})\end{array}$ & $\begin{array}{c}\text { Bulk } \\
\text { Density } \\
\left(\mathrm{kg} / \mathrm{m}^{3}\right)\end{array}$ & $\begin{array}{l}\text { Dry } \\
\text { Matter } \\
(\%)\end{array}$ & Ash (\%) & $\begin{array}{c}\text { Thermal } \\
\text { Conductivity } \\
\lambda(\mathrm{W} / \mathrm{m} \cdot \mathrm{K})\end{array}$ & $\begin{array}{c}\text { Volume Heat } \\
\text { Capacity } \times \\
10^{-6}\left(\mathrm{~J} / \mathrm{m}^{3} \cdot \mathrm{K}\right)\end{array}$ & $\begin{array}{c}\text { Thermal } \\
\text { Diffusivity } \times \\
10^{6}\left(\mathrm{~m}^{2} / \mathrm{s}\right)\end{array}$ \\
\hline G-3/00T & 1200 & $30-50$ & 93 & 20 & 0.0595 & 0.1709 & 0.3478 \\
\hline
\end{tabular}

\subsection{Preparation of Fiber-Reinforced Cement Mortar}

The fiber cement mixtures were prepared in accordance with standard [33]. In the mix design, the weight proportion of cement: sand: water was kept at 1:3:0.55. The RPC (cement mixture with cellulosic fibers) and RPCP (cement mixture with cellulosic fibers and plasticizer) mixtures contained $0.5 \mathrm{wt} \%$ in the addition of the recycled cellulosic fibers from filler and binder weights. Superplasticizer in the amount of $0.5 \mathrm{wt} \%$ by weight of cement was additionally added to the RPCP mixture. Reference mixture (RF-without fiber and plasticizer) was also prepared.

The soaking of recycled fibers and manual mixing in approximately $50 \mathrm{wt} \%$ of water was the first step in the preparation of the mixture. Next, the remaining water, plasticizer (only for RPCP sample), the required amount of sand, and the cement were mixed by mechanical stirring in a mixer. The fresh fiber cement mixture was cast in a standard steel prism with dimensions of $40 \times 40 \times 160 \mathrm{~mm}$. Consequently, consolidation was made for mixture with paper fibers by a jolting apparatus and for mixture with paper fibers and plasticizer by a vibrating table. The samples were demolded after $24 \mathrm{~h}$ and cured for 3, 7, 28, and 90 days in water bath (under laboratory conditions at a temperature of $20^{\circ} \mathrm{C}$ ). Each parameter value is the average of three measurements of the prismatic bodies.

\subsection{Methods of Testing Prepared Fiber Cement Composite Specimens}

Flow behavior of the freshly prepared fiber cement specimen (indicating its workability) was estimated by a flow table test in accordance with standard [36]. Densities of fiber cement composites were calculated after 28 days of hardening [37]. The coefficients of thermal conductivity of hardened fiber cement composites were measured on surface specimens by using the commercial device ISOMET 2114 (Figure 2). Three specimens were prepared to measure thermal conductivity $(140 \times 40 \times 160 \mathrm{~mm})$. Each measurement was repeated five times, and the mean value was reported. The compressive strength of fiber cement composites was also tested according to standard [38] by using a compression test machine (FORM+TEST Seidner \& Co. GmbH, Riedlingen, Germany) with a loading rate $2400 \pm 200 \mathrm{~N} / \mathrm{s}$ after 1, 3, 7, 28, and 90 days of hardening. Three-point bending test was used for 
the determination of flexural strength on the aforementioned testing machine with a loading rate of $50 \pm 10 \mathrm{~N} / \mathrm{s}$.

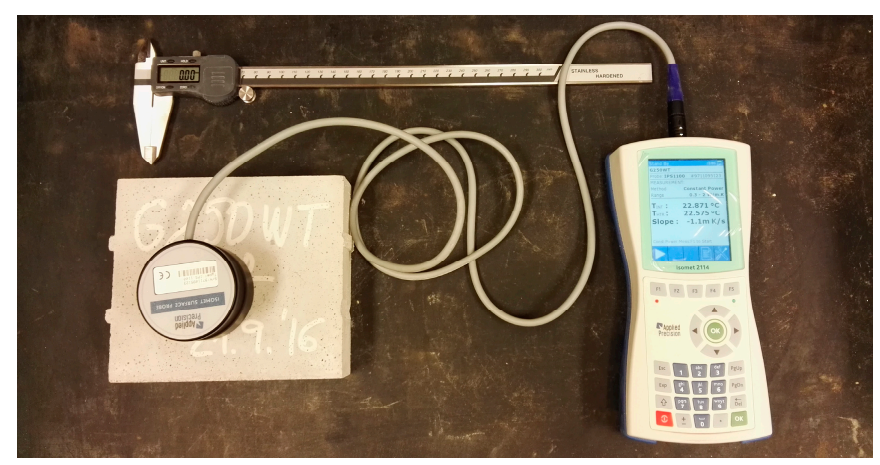

Figure 2. Thermal conductivity measurement of cement composites based on recycled waste paper.

\section{Results and Discussion}

\subsection{Flow Behavior of Fiber-Reinforced Cement Mortar}

The rheology, and hence the flowability, is a parameter that indicates the workability of fresh fiber cement paste. Determination of the workability of the fresh cement matrix based on cellulosic fibers was obtained by the flow table test. The diameters of the resulting flow of mixtures with recycled waste paper fiber (RPC sample without superplasticizer) and with the addition of superplasticizer (RPCP sample) are shown in Figure 3. These values were compared with the reference mixture (RF).

The results of the flow table test for fresh fiber cement paste are presented in Table 2. A constant water/cement ratio of 0.55 was used for the preparation of each fiber cement mixture. The values obtained for fresh RF, RPC, and RPCP pastes were $239 \mathrm{~mm}, 124 \mathrm{~mm}$, and $135 \mathrm{~mm}$, respectively. As can be seen, the used plasticizer had a positive effect on the workability of the RPCP fresh fiber cement paste; the difference in workability between RPCP and RPC cement paste without plasticizer was $5 \%$.

Generally, cellulosic fibers are hydrophilic in nature. This characteristic cause fibers to retain water and swell; fresh fiber cement mixture becomes less fluid and more compact with an increase in the amount of cellulosic fibers. The influence of cellulosic fibers on the flowability of fresh cement mixture has also been observed in works [39,40]. In [39], a decrease in the workability of fiber cement mixtures with increase in fiber content (without using plasticizer or other chemicals) was observed. In the study [40], using the chemical substance Rheomac led to an effective reduction of water absorption and improvement in the consistency of the cement mixture.

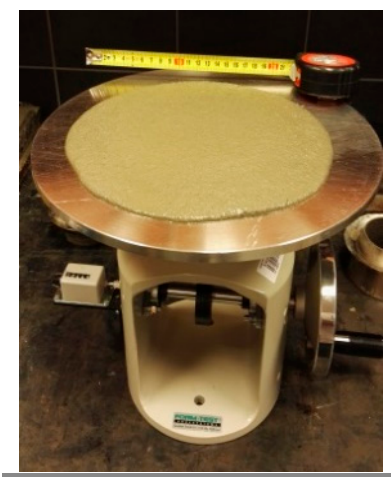

(a)

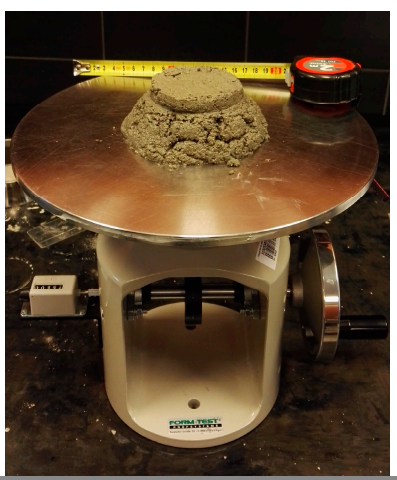

(b)

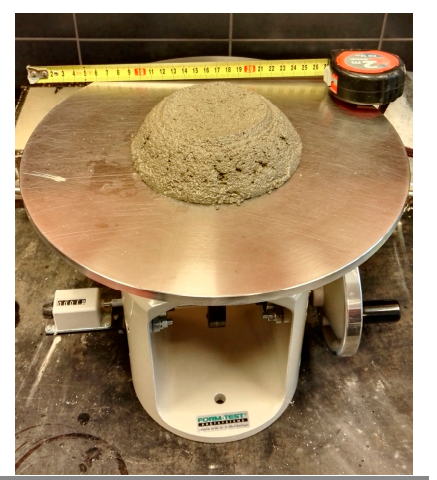

(c)

Figure 3. Flow behavior: (a) Reference sample (RF); (b) Mixture containing $0.5 \%$ waste paper fibers (RPC); (c) Mixture containing $0.5 \%$ waste paper fibers and $0.5 \%$ plasticizer (RPCP). 
Table 2. Flow diameter values of reference sample (RF) and fiber cement mixtures (RPC and RPCP).

\begin{tabular}{cc}
\hline Tested Samples & Flow Diameter Value (mm) \\
\hline RF & 239 \\
RPC & 124 \\
RPCP & 135 \\
\hline
\end{tabular}

\subsection{Density and Thermal Conductivity of Fiber-Reinforced Cement Mortar}

Density and thermal conductivity were determined on the basis of fiber cement composites after 28 days of hardening. Densities of composites contained in the cement matrix cellulosic fibers were within the range of $2090-2244 \mathrm{~kg} / \mathrm{m}^{3}$. While the RF sample had the highest value of density, RPC and RPCP specimens showed lower densities. The maximum reduction in density $(6.8 \%)$ was observed in RPC fiber cement composite when compared to the reference sample.

Figure 4 shows the measured coefficient of thermal conductivity of the prepared fiber cement composites. It can be seen that the thermal conductivity coefficient of RPC and RPCP cement composites decreases with the incorporation of cellulosic waste paper fibers.

The range of thermal conductivity values was $1.78-2.70 \mathrm{~W} / \mathrm{m} \cdot \mathrm{K}$. The RPC composite achieved the best value of thermal conductivity $(1.78 \mathrm{~W} / \mathrm{m} \cdot \mathrm{K})$. In comparison with the RF sample, a $34 \%$ decrease was observed after 28 days of hardening.

Fiber implementation into mixture has a positive effect on the investigated properties such as density and thermal conductivity of fiber cement composites. Figure 4 illustrates a linear relationship between the density and thermal conductivity of tested fiber cement composites after 28 days of hardening. In Figure 4, each point represents the average of 5 measurements of the individual variables. The thermal conductivity of fiber cement composites decreases with decreasing density. Data set in linear, logarithm, exponential, and polynomial trend forms were statistically tested. The value calculated for the correlation coefficient $\mathrm{R}^{2}$ was 0.9466 ; this was found, among others, to be appropriate. This $\mathrm{R}^{2}$ value is approximately the same as the critical value of the correlation coefficient $(0.9500)$ for a set of measured values at elected significance level $p=0.05$.

In accordance with [38], the incorporation of cellulosic fibers into the matrix creates voids and causes heat-insulating properties to enhance with decrease in density. As shown in [41-43], the resulting values of density and thermal conductivity reduce with rise in the cellulosic fiber content in prepared fiber cement specimens.

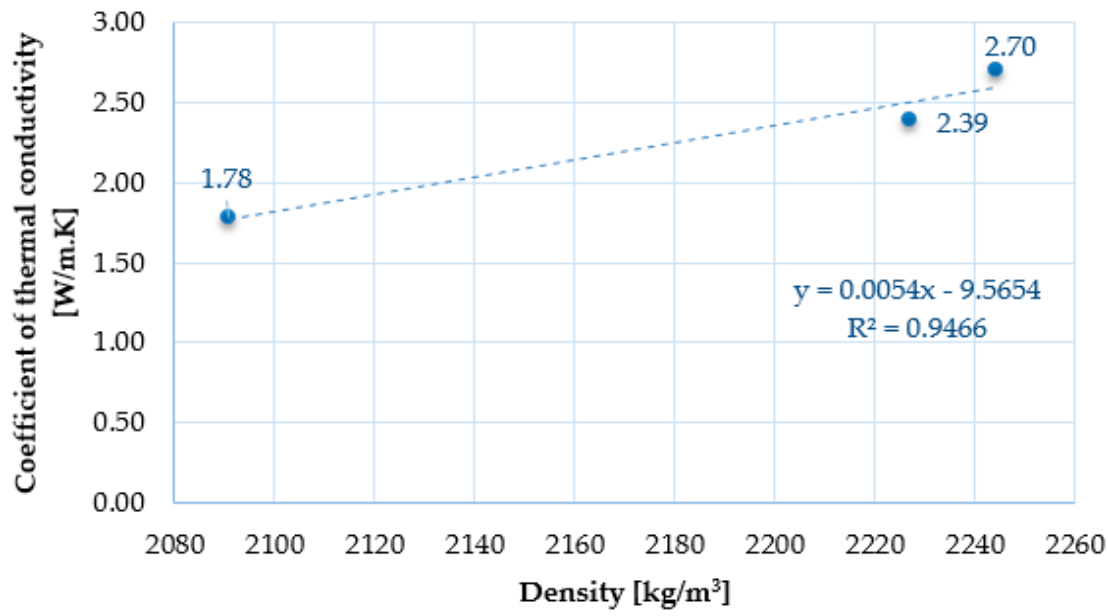

Figure 4. Relationship between density and thermal conductivity of prepared composites. 


\subsection{Mechanical Properties of Fiber-Reinforced Cement Mortar}

Strength properties, such as compressive strength and flexural strength, were observed over a hardening time ranging from 1 day to 90 days. Figure 5 presents the compressive strength development of cement-based composites containing recycled waste paper fibers. As can be seen, the compressive strength parameter ranges up to $32.5 \mathrm{MPa}$ for RPC fiber composites and up to $48.4 \mathrm{MPa}$ for RPCP cement specimens. The latter value is higher than the compressive strength of the RF sample (42 MPa).

The compressive strengths of the reference composite sample, consisting of cement and silica sand, ranged up to $42 \mathrm{MPa}$ for 90 days of hardening. However, as can be seen in Figure 6, flexural strength values were significantly lower. Composite hardened for 90 days only reached one seventh of the compressive strength value. According to the datasheet for CEM I 42.5, the average compressive strength after 90 days of hardening was $67 \mathrm{MPa}$ and the flexural strength was only $9 \mathrm{MPa}$. The strength values found in this paper are comparable in terms of their ratio. However, the strength parameters of fiber cement composites are influenced by water/cement ratio. The lower values of compressive strength fiber cement composites could also be caused by the higher water/cement ratio (0.55) used in comparison to cement paste (0.50).

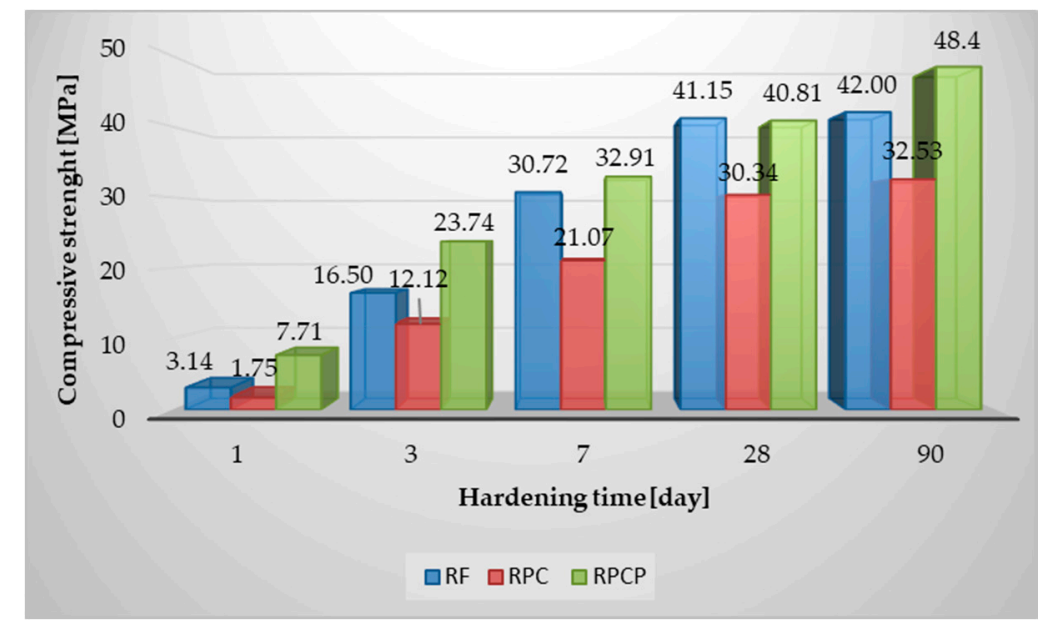

Figure 5. Compressive strength development of specimens up to 90 days.

The values of the flexural strength parameter of the fiber cement composites increased gradually with an increase in the hardening time (Figure 6). Similar to compressive strength, as mentioned above, the trends in the flexural strength development of composites containing waste paper fibers and superplasticizer (RPCP) were the same. The highest flexural strength from fiber cement composites was observed for the RPCP sample after 90 days $(7 \mathrm{MPa})$. RPC composites achieved lower flexural strength by $27 \%$ in comparison to the reference sample. The observed reduction in compressive and flexural strength values of RCP fiber cement composite is probably caused by the air voids formed due to the incorporation of fibers into cement matrix and their mutual insufficient adhesion with binder particles. This interpretation is in accordance with paper [44], where the reduction of bond strength between fibers and the matrix particles led to a decrease in both mechanical strengths. In another study [6], the mechanical properties of waste paper fibers' cement composites was influenced by an effect of the fiber related to its non-uniform dispersion in the matrix; a subsequent weakening could be caused by a reduction of the cementitious matrix volume proportion. As can be seen from results of the flow behavior of fresh mixtures and measurement of mechanical properties of RPCP specimens, admixture of superplasticizer or high-range water reducer based on polycarboxylate ester improved the workability of fiber-reinforced mortars. While the use of superplasticizer maintains fluidity, the small content provides stability of the mix; this results in resistance against bleeding and segregation. The performance of the hardening fresh mixtures improves, and the highest compressive 
and flexural strengths of fiber cement composite specimens at all hardening times is due to the significantly better dispersion of cement particles. The suitable dose of superplasticizer (within the prescribed limits suggested by the producer) must be experimentally determined to reach the required level of workability of fiber cement mixture: this will help in improving the durability of cellulosic fiber in the cement composite [45]. It is generally assumed that superplasticizer molecules are adsorbed on the cement particles in order to develop electrostatic and steric repulsive forces. Based on this fact, the high strength of these composites is also due to the improved bond strength between fibers, paste, and sand particles. The use of polycarboxylate ester superplasticizer facilitates the formation of fiber cement composite structures. It was established in [46] that polycarboxylate SP GleniumACE 430 applied in cement paste facilitates the formation of poorly crystalline hydrate phases consisting mainly of hydrated silicates (C-S-H (II) phase) or tobermorite gel. Polycarboxylate ester superplasticizer or polycarboxylate provides the dispersion of cement particles by steric stabilization, instead of electrostatic repulsion. This form of dispersion is more powerful in its effect and gives improved workability retention to the cementitious mix [47]. The molecules of the superplasticizer hinder water molecules and diffusion of $\mathrm{Ca}^{2+}$ ions across the solution-cement interface. The $\mathrm{Ca}^{2+}$ ions form complexes with the superplasticizer molecules, inhibiting the nucleation and growth of Ca-rich species. The strong dispersive action of these admixtures alters reaction product formation kinetics and morphology [48]. Superplasticizer is adsorbed on the surface of cement particles and modifies the structure of the hydrated matrix. The presence of a superplasticizer in the cement matrix affects the compactness of the structure. The compressive strength of cement composites/mortars depends on a number of factors. These are degree of hydration, quality of cement, sand, $\mathrm{w} / \mathrm{c}$ ratio, temperature, particle size distribution, the pore size, pore-size distribution, etc. However, pore size is one of the most important factors controlling compressive strength. Superplasticizer reduces the pore size or the number of pores and, as a result, the compressive strength is increased [49].

To assess the superplasticizer influence on the phase composition of fiber cement composite structure, further research will be required. As of now, these results are very useful for directing future research to better understand the behavior of cellulosic fibers in cement matrix with superplasticizer.

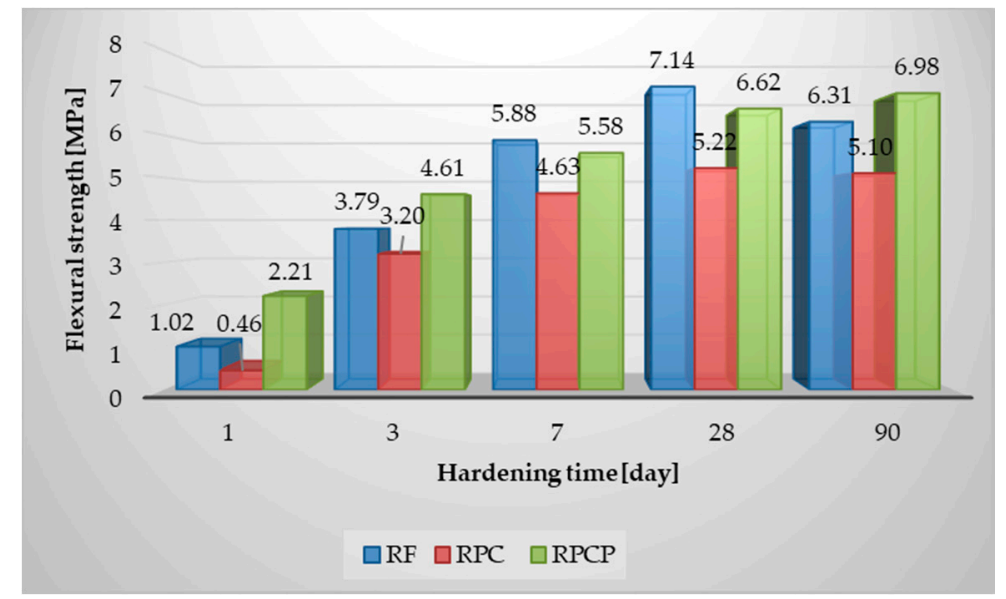

Figure 6. Development of flexural strength of tested specimens over time up to 90 days.

\section{Conclusions}

The purpose of the work was to incorporate the waste material (recycled waste paper fibers) right after its pulping in raw state without further treatment in cement composite mixture for plaster application with thermal insulation properties (especially for interior usage) and to study the behavior of fresh cement mortars based on non-treated cellulosic fibers, as well as to find out their impact on the resulting properties of fiber cement plasters. The effect of superplasticizer on building material 
properties such as consistency of the fresh mixture, density, thermal conductivity, compressive and flexural strength was also investigated.

Waste paper cellulosic fibers were added to the mixture as components of cement mortars at $0.5 \%$ by weight of binder and filler. From the results presented above, it could be concluded that cellulosic fibers have a positive effect on the physical properties of fiber cement composites. Incorporating cellulosic fibers into the cement matrix caused a decrease in density $(6.8 \%)$ and an increase in the coefficient of thermal conductivity (34\%) of cement mortars as compared to specimens without cellulosic fibers after 28 days of hardening.

Superplasticizer use resulted in higher mixture quality, which was due to adsorption of superplasticizer molecules on the cement particles. Consequently, the performance of the hardening fresh mixtures was improved. RPCP fiber composites containing superplasticizer exhibited the best mechanical properties in early hardening times, as well as with regard to the prolongation of the hardening time due to significantly better dispersion of cement particles and improved bond strength between fibers and matrix. RPCP fiber composites containing a superplasticizer exhibited the best mechanical properties in early hardening times, as well as with prolongation of the hardening time up to 90 days (for compressive strength $48.4 \mathrm{MPa}$ and for flexural strength up to $7 \mathrm{MPa}$ ) due to significantly better dispersion of cement particles and improved bond strength between fibers and matrix.

For this application of fiber cement plaster, further research will lead to additional data related to determination of the adhesion of the mortar to the support layer. Based on the presented results, it could be said that the use of waste cellulosic fibers in building materials is an efficient solution with environmental benefit for the construction industry because of saving the natural sources such as trees, energy and water needed for the production of cellulosic fibers. The key aspect of the use of recycled cellulosic fibers in comparison to produced fibers from wood is the environmental protection against the toxic pollutants released in the atmosphere and wastewater treatment is not necessary.

Acknowledgments: The authors are grateful to the Slovak Grant Agency for financial support of the project VEGA 1/0277/15, Project Institute of Clean Technologies for Mining and Utilization of Raw Materials for Energy Use. Reg. No. LO1406 and the student grant competition project SGS SP2017/116.

Author Contributions: Nadezda Stevulova and Viola Hospodarova conceived and designed the experiments; Katarina Kostelanska provided recycled cellulosic fibers and their characterization; Viola Hospodarova performed the experiments; Nadezda Stevulova and Viola Hospodarova analyzed the data; Jaroslav Briancin contributed with SEM analysis; Nadezda Stevulova and Viola Hospodarova wrote the paper.

Conflicts of Interest: The authors declare no conflict of interest.

\section{References}

1. Gola, L.; Václavík, V.; Valíček, J.; Harničárová, M.; Kušnerová, M.; Dvorský, T. Drainage concrete based on cement composite and industrial waste. Adv. Struct. Mater. 2015, 70, 155-165. [CrossRef]

2. Václavík, V.; Dvorský, T.; Dirner, V.; Daxner, J.; Št'astný, M. Polyurethane foam as aggregate for thermal insulating mortars and lightweight concrete. Teh. Vjesn. 2012, 19, 665-672.

3. Vaclavik, V.; Valicek, J.; Novosad, M.; Stankova, H.; Bendova, M.; Daxner, J. Monitoring of deformation of thermal insulating plaster with fillers from recycled polyurethane foam using conventional geodetic methods. In Proceedings of the International Multidisciplinary Scientific GeoConference: SGEM: Surveying Geology \& Mining Ecology Management, Albena, Bulgaria, 17-23 June 2012; Volume 4, p. 719.

4. Stevulova, N.; Vaclavik, V.; Junak, J.; Grul, R.; Bacikova, M. Utilization possibilities of selected waste kinds in building materials preparing. In Proceedings of the 8th International Scientific Conference-SGEM2008, Sofia, Bulgaria, 16-20 June 2008.

5. Wei, J.A.; Meyer, C. Degradation mechanisms of natural fiber in the matrix of cement composites. Cem. Concr. Res. 2015, 73, 1-16. [CrossRef]

6. Bentchikou, M.; Guidoum, A.; Scrivener, K.; Silhadi, K.; Hanini, S. Effect of recycled cellulose fibres on the properties of lightweight cement composite matrix. Constr. Build. Mater. 2012, 34, 451-456. [CrossRef]

7. Onuaguluchi, O.; Banthia, N. Plant-based natural fibre reinforced cement composites: A review. Cem. Concr. Res. 2016, 68, 96-108. [CrossRef] 
8. Xie, X.; Zhou, Z.; Jiang, M.; Xu, X.; Wang, Z.; Hui, D. Cellulosic fibers from rice straw and bamboo used as reinforcement of cement-based composites for remarkably improving mechanical properties. Compos. Part B Eng. 2015, 78, 153-161. [CrossRef]

9. Dalmay, P.; Smith, A.; Chotard, T.; Sahay-Turner, P.; Gloaguen, V.; Krausz, P. Properties of cellulosic fibre reinforced plaster: Influence of hemp or flax fibres on the properties of set gypsum. J. Mater. Sci. 2010, 45, 793-803. [CrossRef]

10. Tonoli, G.H.D.; Rodrigues Filho, U.P.; Savastano, H.; Bras, J.; Belgacem, M.N.; Lahr, F.R. Cellulose modified fibres in cement based composites. Compos. Part A Appl. Sci. Manuf. 2009, 40, 2046-2053. [CrossRef]

11. Mármol, G.; Santos, S.F.; Savastano, H.; Borrachero, M.V.; Monzó, J.; Payá, J. Mechanical and physical performance of low alkalinity cementitious composites reinforced with recycled cellulosic fibres pulp from cement kraft bags. Ind. Crop. Prod. 2013, 49, 422-427. [CrossRef]

12. Anju, T.R.; Ramamurthy, K.; Dhamodharan, R. Surface modified microcrystalline cellulose from cotton as a potential mineral admixture in cement mortar composite. Cem. Concr. Compos. 2016, 74, 147-153. [CrossRef]

13. Mohammadkazemi, F.; Doosthoseini, K.; Ganjian, E.; Azin, M. Manufacturing of bacterial nano-cellulose reinforced fiber-cement composites. Constr. Build. Mater. 2015, 101, 958-964. [CrossRef]

14. Ghavami, K. Bamboo as reinforcement in structural concrete elements. Cem. Concr. Compos. 2005, 27, 637-649. [CrossRef]

15. Stevulova, N.; Schwarzova, I.; Hospodarova, V.; Junak, J. Implementation of waste cellulosic fibres into building materials. Chem. Eng. Trans. 2016, 50, 367-372. [CrossRef]

16. Balčiūnas, G.; Pundienè, I.; Lekūnaitè-Lukošiūnè, L.; Vejjelis, S.; Korjakins, A. Impact of hemp shives aggregate mineralization on physical-mechanical properties and structure of composite with cementitious binding material. Ind. Crop. Prod. 2015, 77, 724-734. [CrossRef]

17. Cigasova, J.; Stevulova, N.; Schwarzova, I. Innovative Use of Plant Wastes-Hemp Hurds Slices. Chem. Eng. Trans. 2016, 50, 373-378. [CrossRef]

18. Andiç-Çakir, O.; Sarikanat, M.; Tüfekçi, H.B.; Demirci, C.; Erdogan, Ü.H. Physical and mechanical properties of randomly oriented coir fiber-cementitious composites. Compos. Part B Eng. 2014, 61, 49-54. [CrossRef]

19. Ardanuy, M.; Claramunt, J.; Toledo Filho, R.D. Cellulosic fiber reinforced cement-based composites: A review of recent research. Constr. Build. Mater. 2015, 79, 115-128. [CrossRef]

20. Soydan, A.M.; Sari, A.K.; Duymaz, B.; Akdeniz, R.; Tunaboylu, B. Air-cured fiber-cement composite mixtures with different types of cellulose fibers. Adv. Mater. Sci. Eng. 2018, 2018, 1-9. [CrossRef]

21. Ferreira, S.R.; Pepe, M.; Martinelli, E.; de Andrade Silva, F.; Toledo Filho, R.D. Influence of natural fibers characteristics on the interface mechanics with cement based matrices. Compos. Part B Eng. 2018, 140, 183-196. [CrossRef]

22. Bentchikou, M.; Guidoum, A.; Scrivener, K.; Silhadi, K.; Hanini, S. Effect of cellulose fibre on the thermal and mechanical properties of cement paste. In Proceedings of the International RILEM Conference on the use of recycled materials in buildings and structures, Barcelona, Spain, 8-11 November 2004; Volume 2.

23. De Andrade Silva, F.; Toledo Filho, R.D.; de Almeida Melo Filho, J.; Fairbairn, E.D.M.R. Physical and mechanical properties of durable sisal fiber-cement composites. Constr. Build. Mater. 2010, 24, 777-785. [CrossRef]

24. Aciu, C.; Iluţiu-Varvara, D.A.; Cobirzan, N.; Balog, A. Recycling of paper waste in the composition of plastering mortars. Procedia Technol. 2014, 12, 295-300. [CrossRef]

25. Gomes, L.M.; Aroche, A.; Schafer, M.; Erhart, R.; Moraes, C.A.M.; de Campos Rocha, T.L.A.; Brehm, F.A. Influence of cellulose pulp waste in plastering mortar. Key Eng. Mater. 2015, 634, 222-234. [CrossRef]

26. Wei, J.; Ma, S.; D'Shawn, G.T. Correlation between hydration of cement and durability of natural fiber-reinforced cement composites. Corros. Sci. 2016, 106, 1-15. [CrossRef]

27. Wei, J.; Meyer, C. Utilization of rice husk ash in green natural fiber-reinforced cement composites: Mitigating degradation of sisal fiber. Cem. Concr. Res. 2016, 81, 94-111. [CrossRef]

28. Al-Amoudi, O.S.B.; Al-Kutti, W.A.; Ahmad, S.; Maslehuddin, M. Correlation between compressive strength and certain durability indices of plain and blended cement concretes. Cem. Concr. Compos. 2009, 31, 672-676. [CrossRef] 
29. Silva, F.A.; Melo Filho, J.A.; Toledo Filho, R.D.; Fairbairn, E.M.R. Mechanical behavior and durability of compression moulded sisal fiber cement mortar laminates (SFCML). In Proceedings of the 1st International RILEM Conference on Textile Reinforced Concrete (ICTRC), Aachen, Germany, 5-7 September 2006; RILEM Publications SARL: Paris, France, 2006; pp. 171-180.

30. Tonoli, G.H.D.; Belgacem, M.N.; Siqueira, G.; Bras, J.; Savastano, H.; Lahr, F.R. Processing and dimensional changes of cement based composites reinforced with surface-treated cellulose fibres. Cem. Concr. Compos. 2013, 37, 68-75. [CrossRef]

31. Neithalath, N.; Weiss, J.; Olek, J. Acoustic performance and damping behavior of cellulose-cement composites. Cem. Concr. Compos. 2004, 26, 359-370. [CrossRef]

32. Khorami, M.; Ganjian, E. Comparing flexural behaviour of fibre-cement composites reinforced bagasse: Wheat and eucalyptus. Constr. Build. Mater. 2011, 25, 3661-3667. [CrossRef]

33. STN EN 196-1: 2016. Methods of Testing Cement. Part 1: Determination of Strength; Slovak Office of Standards, Metrology and Testing: Bratislava, Slovakia, 2016.

34. STN EN 1008: 2003. Mixing Water Concrete. Specification for Sampling, Testing and Assessing the Suitability of Water, Including Water Recovered from Processes in the Concrete Industry, as Mixing Water for Concrete; Slovak Office of Standards, Metrology and Testing: Bratislava, Slovakia, 2003.

35. STN EN 934-2+A1: 2013. Admixtures for Concrete, Mortar and Grout. Part 2: Concrete Admixtures Definitions, Requirements, Conformity, Marking and Labeling; Slovak Office of Standards, Metrology and Testing: Bratislava, Slovakia, 2013.

36. STN EN 1015-3/A2: 2007. Methods of Test for Mortar for Masonry. Part 3: Determination of Consistence of Fresh Mortar (by Flow Table); Slovak Office of Standards, Metrology and Testing: Bratislava, Slovakia, 2007.

37. STN EN 1015-10/A1: 2007. Methods of Test for Mortar for Masonry. Part 10: Determination of Dry Bulk Density of Hardened Mortar; Slovak Office of Standards, Metrology and Testing: Bratislava, Slovakia, 2007.

38. STN EN 1015-11/A1: 2007. Methods of Test for Mortar for Masonry. Part 11: Determination of Flexural and Compressive Strength of Hardened Mortar; Slovak Office of Standards, Metrology and Testing: Bratislava, Slovakia, 2007.

39. Chakraborty, S.; Kundu, S.P.; Roy, A.; Basak, R.K.; Adhikari, B.; Majumder, S.B. Improvement of the mechanical properties of jute fiber reinforced cement mortar: A statistical approach. Constr. Build. Mater. 2013, 38, 776-784. [CrossRef]

40. Sawsen, C.; Fouzia, K.; Mohamed, B.; Moussa, G. Effect of flax fibers treatments on the rheological and the mechanical behavior of a cement composite. Constr. Build. Mater. 2015, 79, 229-235. [CrossRef]

41. Onésippe, C.; Passe-Coutrin, N.; Toro, F.; Delvasto, S.; Bilba, K.; Arsène, M.A. Sugar cane bagasse fibres reinforced cement composites: Thermal considerations. Compos. Part A Appl. Sci. Manuf. 2010, 41, 549-556. [CrossRef]

42. Asasutjarit, C.; Hirunlabh, J.; Khedari, J.; Charoenvai, S.; Zeghmati, B.; Shin, U.C. Development of coconut coir-based lightweight cement board. Constr. Build. Mater. 2007, 21, 277-288. [CrossRef]

43. Khedari, J.; Suttisonk, B.; Pratinthong, N.; Hirunlabh, J. New lightweight composite construction materials with low thermal conductivity. Cem. Concr. Compos. 2001, 23, 65-70. [CrossRef]

44. Raut, A.N.; Gomez, C.P. Thermal and mechanical performance of oil palm fiber reinforced mortar utilizing palm oil fly ash as a complementary binder. Constr. Build. Mater. 2016, 126, 476-483. [CrossRef]

45. Ramakrishna, G.; Sundararajan, T. Effect of superplasticizer on the rheological properties of coir fibre reinforced cement mortar. In Proceedings of the 27th conference on our world in concrete \& structures, Singapore, 29-30 August 2002; Singapore Concrete Institute: Singapore, 2002; pp. 489-492.

46. Shuldyakov, K.; Kramar, L.; Trofimov, B.; Ivanov, I. Superplasticizer effect on cement paste structure and concrete freeze-thaw resistance. AIP Conf. Proc. 2016, 1698, 070011. [CrossRef]

47. Mohan, R.; Jadhav, V.; Ahmed, A.; Rivas, J.; Kelkar, A. Effect of Plasticizer Additives on the Mechanical Properties of Cement Composite-A Molecular Dynamics Analysis. Int. J. Chem. Mol. Nucl. Mater. Metall. Eng. 2014, 8, 84-88. 
48. Puertas, F.; Santos, H.; Palacios, M.; Martínez-Ramírez, S. Polycarboxylate superplasticiser admixtures: Effect on hydration, microstructure and rheological behaviour in cement pastes. Adv. Cem. Res. 2005, 17, 77-89. [CrossRef]

49. Kumar, M.; Singh, N.P.; Singh, S.K.; Singh, N.B. Combined effect of sodium sulphate and superplasticizer on the hydration of fly ash blended Portland (R) cement. Mater. Res. 2010, 13, 177-183. [CrossRef] 